\title{
Proceeding
}

Supplementary Issue: Autumn Conferences of Sports Science. Costa Blanca Sports Science Events, 2-3 November 2018.

Alicante, Spain

\section{The training of physical education teacher in primary school}

\author{
FRANCESCA D'ELIA \\ University of Salerno, Italy
}

\begin{abstract}
In 2018 the Italian government has proposed a bill to develop Physical Education PE in Primary school. The focus is the qualifications of Primary teachers throughout PE degree course for teaching qualifications instead the generalist training, as well as it happens in secondary school. Aim is to point out the core curriculum to become a specialist teacher of PE in the Italian primary school. It is a mapping activity providing a comparative data from all 38 Italian degree course in PE. It based on declared learning outcomes of four areas of knowledge: 1. sport and physical activity; 2. biological, biomedical and clinical; 3. psicopedagogical; 4. historical, legal, economic, statistical and sociological. Results shows that the percentage of degree course that curriculum focus on PES is 34\%, while the percentage of curricula, focused on biological, biomedical and clinical area is $63 \%$. It seems that, despite University aims to train professional in the field of PE, the degree courses of PE are mainly shaped to build biological, biomedical and clinical skills instead professional skills of PES. The core curriculum should be aim on the strict elements of physical training and sport sciences methodology and should have the same structure plane of subjects on all of 38 universities. Key words: Core curriculum; Specialist teacher; Sport science degree.
\end{abstract}

\section{Cite this article as:}

D‘Elia, F. (2019). The training of physical education teacher in primary school. Journal of Human Sport and Exercise, 14(1 proc), S100-S104. doi:https://doi.org/10.14198/ihse.2019.14.Proc1.12

Corresponding author. University of Salerno, Italy.

E-mail: fdelia@unisa.it

Supplementary Issue: Autumn Conferences of Sports Science. Costa Blanca Sports Science Events, 2-3 November 2018. Alicante, Spain.

JOURNAL OF HUMAN SPORT \& EXERCISE ISSN 1988-5202

(C) Faculty of Education. University of Alicante.

doi:10.14198/jhse.2019.14.Proc1.12 


\section{INTRODUCTION}

In Italy to teach in pre-school and in primary school is needed a Master's degree in Science of Primary Education. This master's degree lasts five years and prescribes three main types of educational activities: academic class, workshop (on the subject of academic class) and internship at school. The internship lasts 600 hours (equivalent to 24 university credit) and it should be carried out directly at school and indirectly through courses and workshop held by tenured teacher of pre-school and of primary school. The academic class and the related workshop are mainly related to some generalist disciplines (Pedagogy, Didactic and Psychology) and peripheral (in terms of university credit) to some specialist disciplines (Italian Language, Mathematics, History, Geography, English, Arts, Physical Education, Physics and Biology). It appears that the training to become a pre-school and a primary school teacher is a demanding path (Raiola 2011ab), but despite both generalist and specialist training of teachers, some specialist disciplines are badly affected by a summary training that don't get ready to specialized teach.

Therefore in 2015 the law n. 107 (art. 1, co. 20) has established that, in addition to people licensed to teach in primary school, (in primary school) could be also involved secondary school teachers that are specialized on physical education. This law has been not enough to bridge the gap of specialized PE teacher in primary school, so in 2018 the Italian government has proposed a public bill to develop and encourage Physical Education in primary school. The key element of the bill is the qualifications of teachers involved in physical education school programs as in the Italian primary schools, like in other European Countries (Eurydice, 2013), are employed only generalist teachers for this purpose, while at (lower and high) secondary level specialist teachers of physical education are the norm.

More in detail, the bill that to teach physical education in primary school is needed a bachelor's degree in Sport Science. Whereas, since 2000, to teach physical education in secondary (lower and high) school is needed a master's degree in Sport Science and a training course.

Since 2004 (Low n. 270) the degree courses in Italy are grouped in "families" of degrees depending on similarity of learning outcomes and job positions; this low guarantee that the $50 \%$ of University Credits to graduate is related to standard Academic Disciplines, whereas the remaining $50 \%$ is characteristic of each University. Bachelor's degrees in Sport Science are grouped in a single family of degree (L22), whereas master's degrees in Sport Science are grouped in three families of degree: 1. sport science LM68; 2. adapted activity LM67; 3. management of sport LM47 (D'Elia et al., 2018; Raiola et al., 2018).

\section{AIM}

The present study is a report on curricula of Sport Science (Bachelor) Degree Course in Italy aimed at point out the core curriculum to become a specialist teacher of physical education in the Italian primary school. It is a short mapping activity providing a comparative information from all 38 Italian Degree Course in Sport Science and Physical Education, starting from the standard University Credit and focusing on the characteristic percentage of Academic Discipline of each University.

\section{METHODOLOGY}

Document analysis was conducted. It has been analysed 38 data sheets related to the Italian Sport Science Bachelor's Degree Courses. Data sheets are comprehensive information booklets that include details on learning outcomes, study plan, learning environment and much more information about the course. 
Data collection was based on declared learning outcomes according to four areas of knowledge; each area unifies different academic disciplines and it is based on coherence and similarity:

1. SPORT and PE area, that unify the academic disciplines on sport and physical activities, including practice exercises;

2. BIO area; that unify the academic disciplines on biological, biomedical and clinical aspect of locomotion and of sport;

3. PSICOPEDAGOGICAL area; that unify the academic disciplines on pedagogy, didactic and psychology;

4. COLLECTION area, that unify historical, legal, economic, statistical and sociological academic disciplines.

It has been compared the University Credits of academic disciplines, making an estimate of importance and prevalence of each area in relation to the other.

\section{RESULTS}

Data analysis shows that the percentage of Degree Courses of Sport Science in Italy that focus their curriculum mainly on SPORT and PE area is $34 \%$, while the percentage of curricula focused on BIO area is $63 \%$. In only one case the prevalence area is PSICOPEDAGOGICAL.

\section{DISCUSSION}

It seems that despite University is called to train professional in the field of physical education and sport, the Sport Science (Bachelor) Degree Courses in Italy are mainly shaped to build biological, biomedical and clinical skills instead of skills about design, management, planning and assessment of sport and physical activities. The job positions outcoming from bachelor's degree in sport science should be directed to both technical and educational aspects and based on the awareness that during childhood physical education should not be limited to training of physical skills, (D'Isanto 2016; Altavilla et al., 2016; Valentini et al., 2018a), because has more than just a technical or a recreational dimension and it could enhance educational goals, lifelong fitness and good health (Raiola, 2013; Raiola, 2014; Raiola, 2015; Di Tore et al., 2016; Valentini, 2018b).

In particular, the current curricula lacks contents and learning outcomes centred on sport and PE, in spite of recommendation of the National Council of the Heads of Department of Sport Sciences to address to sport and PE area the $70 \%$ of contents of each discipline.

Core curriculum should consider specific contents about knowledge and understanding in sport science and $P E$, ensuring that student will be able to apply these knowledges and understanding.

In particular, physical education and sport at school cannot be limited to improving just physical abilities, because it covers a broader range of skills, as emotional, social, cognitive and moral concepts. So the physical (promotion of health and healthy lifestyle, including lifelong enjoyment in physical activity and exercise), personal (development of physical awareness, self-confidence and self-esteem, sense of responsibility, patience and courage, balanced mental attitudes) and social (sense of solidarity, social interaction, team work and team spirit, fair play, respect for rules and for others) development of children is a main educative goal to which direct learning outcomes. 


\section{CONCLUSION}

According to the need to qualify specialist teachers of physical education for the primary school, core curriculum of the Degree Course in Sport Science in Italy should be focused mainly on the sport and physical activity area of knowledge, studying in deep how to teach (and to learn through) sport and physical education during childhood.

In addiction to specify contents and learning outcomes to become primary school PE teacher it is also necessary to reach a compromise between the master's degrees needed to teach in primary school and to teach physical education in secondary school, equalizing prerequisites to teach physical education in primary school.

\section{REFERENCES}

Altavilla, G., Di Tore, P.A.(2016) Physical education during the first school cycle: A brief social psychopedagogical summary, Journal of Physical Education and Sport, 16 (2), art. no. 55, pp. 340-344.

D'Isanto, T. (2016) Pedagogical value of the body and physical activity in childhood [Pedagoška vrijednost tijela i tjelesne aktivnosti u djetinjstvu] Sport Science, 9, pp. 13-18.

D'santo, T., Di Tore, P.A. (2016). Physical activity and social inclusion at school: A paradigm change, Journal of Physical Education and Sport, 16, pp. 1099-1102.

D'elia, F., Mazzeo, F., Raiola, G. (2018) The core curriculum in the university training of the teacher of physical education in Italy, Journal of Human Sport and Exercise, 13, pp. S413-S420. https://doi.org/10.14198/ihse.2018.13.Proc2.25

Di Tore, P.A., Schiavo, R., D'Isanto, T. (2016) Physical education, motor control and motor learning: Theoretical paradigms and teaching practices from kindergarten to high school, Journal of Physical Education and Sport, 16 (4), art. no. 205, pp. 1293-1297.

European Commission/EACEA/Eurydice, 2013. Physical Education and Sport at School in Europe Eurydice Report. Luxembourg: Publications Office of the European Union.

Raiola, G. (2011a) A study on Italian primary school rules: Neurophysiological and didactics aspects In physical education and sport, Journal of Physical Education and Sport, 11 (2), pp. 43-48.

Raiola, G. (2011b)Study between neurophysiological aspects and regulation documents on preschool in Italy, Journal of Physical Education and Sport, 11 (1), pp. 42-47.

Raiola, G. (2013). Body knowledge and motor skills, Knowledge Cultures, 1 (6), pp. 64-72.

Raiola, G. (2014). Motor control and learning skills according to cognitive and ecological dynamic approach in a vision on behaviorism, cognitive, Gestalt and phenomenology theories, Mediterranean Journal of Social Sciences, 5 (15), pp. 504-506.

Raiola, G. (2015). Sport skills and mental health. Journal of Human Sport and Exercise, 10(1proc), S369S376. doi:https://doi.org/10.14198/ihse.2015.10.Proc1.27

Raiola, G. (2017). Motor learning and teaching method, Journal of Physical Education and Sport, 17, pp. 2239-2243.

Raiola, G., Di Tore, P.A. (2017)Motor learning in sports science: Different theoretical frameworks for different teaching methods [Motoričko učenje u sportskoj znanosti: Različiti teorijski okviri za različite metode poučavanja] Sport Science, 10, pp. 50-56.

Raiola, G., D'elia, F., Altavilla, G. (2018) Physical activity and sports sciences between European Research Council and academic disciplines in Italy, Journal of Human Sport and Exercise, 13, pp. S283-S295. https://doi.org/10.14198//hse.2018.13.Proc2.13 
Senatore B., D'Elia, F., (2018) Rhythmic gymnastics and dyslexia: a two-year preliminary case study, Journal of Physical Education and Sport, 18 Supplement issue 5, pp. 2122 - 2126.

Tiziana, D., Antonetta, M., Gaetano, A. (2017) Health and physical activity [Zdravlje i tjelesna aktivnost] Sport Science, 10 (1), pp. 100-105.

Tore, A.D., Altavilla, G., D'Isanto, T. (2018)Situation awareness in sports science: Beyond the cognitive paradigm, Sport Science, 11 (1), pp. 25-28.

Valentini, M., Bernardini, C., Beretta, A., Raiola, G. (2018a). Movement and language development as an early childhood twin strategy: A systematic review, Sport Mont, 16 (3), pp. 107-112.

Valentini, M., Riccardi, F., Raiola, G., Federici, A. (2018b). Educational research: Motor area and relational area during children's personality development, Journal of Physical Education and Sport, 18 , art. no. 327 , pp. 2157-2174.

\section{(c) (i) $\ominus$}

This work is licensed under a Attribution-NonCommercial-NoDerivatives 4.0 International (CC BY-NC-ND 4.0). 